\title{
Is VAT Administration System Efficient?' The case of the Czech Republic
}

\author{
Hana Zídková \\ Prague University of Economics and Business, The Czech Republic \\ hana.zidkova@vse.cz \\ https://orcid.org/0000-0003-3661-6993

\section{Tomáš Vrána} \\ Prague University of Economics and Business, The Czech Republic \\ vrat02@vse.cz \\ https://orcid.org/0000-0002-4006-1794
}

Received: 13. 7. 2020

Accepted: 8. 10. 2020

\section{ABSTRACT}

This paper is focused on the efficiency of VAT collection under the standard credit invoice method. It discusses several approaches on how to evaluate the efficiency of the VAT system. The authors create their own indicator called the C-Coefficient that determines how many times must one unit of currency be checked by the financial authority to collect it into public budgets. The C-Coefficient is calculated from the data on VAT revenues and total VAT paid on all taxable supplies performed in the economy. The concrete results are shown for the Czech Republic for the period 2005 to 2018. The C-Coefficient reaches the values between 7.92 and 11.56, meaning that in the most efficient year (2018) the tax authorities had to inspect each collected CZK more than 7 times, whereas in the least efficient year (2008) they had to audit each collected CZK more than 11 times. Authors also discuss what influences the C-Coefficient. Among important factors are measures against VAT fraud, especially the specific reverse charge, as well as the number of VAT payers in the pro-duction and distribution chain and the difference between the average VAT rates applicable on final and intermediate consumption.

Keywords: C-Coefficient, definitive VAT system, final consumption, intermediate consumption, reverse charge, VAT efficiency, collection efficiency, Czech Republic

JEL: H21, H26

1 The paper was prepared as one of the outputs of a research project of the Faculty of Finance and Accounting at the University of Economics „Economic and institutional aspects of public finance" registered by the Internal Grant Agency of University of Economics, Рrague under the registration number F1/7/2019 and it was also funded by the institutional support IP 100040 at the Faculty of Finance and Accounting at the University of Economics. 


\section{Introduction}

Value added tax is an important source of public revenues for all European Union countries. However, its collection is affected by significant tax evasion. A recent study by (Poniatowski et al., 2019) estimated the so-called VAT gap in the EU at EUR 137 billion in 2019. In relative terms, it is $11.7 \%$ of theoretical tax liability. The VAT gap is an expression of tax evasion as we explain in more detail in next section. A significant part of total VAT gap is represented by chain or carousel frauds, which consist in not paying output tax by a supplier and claiming it by a customer. The imposters abuse the current system of cross-border supplies' taxation in the EU. More precisely, they exploit the VAT exemption of cross-border supply and effectively VAT free intracommunity acquisition of goods ${ }^{2}$. These fraudsters purchase the goods from other Member State, sell it locally without remitting the VAT due to the tax authority and become so called "Missing traders". The details on carousel fraud (further also "MTIC fraud") can be found in Ainsworth (2011), European Court of Auditors (2016) or Fedeli and Forte (2017).

To combat the alarming VAT fraud, Member States are trying various anti-fraud measures. Among other things, they implement reverse charge mechanism for VAT collection on certain commodities most threatened by VAT fraud. Also, the temporary application of general reverse charge to all goods and services is considered. An optional exception from the standard way of VAT collection was implemented in the European Council Directive 2018/2058. Reverse charge transfers the obligation to report the output tax payable from transactions to purchasers who at the same time claim input tax deduction. Suppliers in the distribution chain do not charge any output tax and the goods and services are effectively sold without VAT. This is completely different way of VAT collection from the standard VAT system where the suppliers apply output VAT on their sales and remit it to the financial authorities whereas buyers pay input VAT in the price of purchased goods and services and claim it back from the tax administrator. Thus, the VAT is collected in stages, each VAT payer in the supply chain remits only the amount of VAT from their added value because they calculate the VAT liability as the difference between total their output tax and input tax in the tax period. This method of VAT collection is called a credit invoice method (Terra and Kajus, 2015). In the reverse charge system, VAT is charged mostly by suppliers at the end of the supply chain when the goods or services are supplied to the end consumer; and in that moment, VAT is collected by tax authorities.

On the other hand, the European Commission has been working to find a conceptual solution to prevent tax evasion which was described for example in the Green paper on VAT (European Commission, 2010). After extensive discussions, the preferred route is taxing the supply of goods (and later also services) within the EU instead of exempting them from VAT, which should prevent carousel fraud. In the future, under so called "Definitive VAT system",

2 The purchaser must report the output tax but also have the right to claim the same amount as input tax in his VAT return. 
supplies should be taxed by the supplier at the rate applicable in the country of destination (European Commission, 2018). The place of supply of crossborder sales would be newly determined in the country where the shipment ends. The supplier would pay VAT on the supply to another Member State through a special tax return, the so-called "One Stop Shop". This VAT would be collected by the Member State of the supplier but transferred to the Member State where the goods are transported to.

The Definitive VAT system uses for cross-border transactions a credit invoice method described above which is currently applicable on local supplies. This method consists in remittance of output VAT from each transaction by supplier to tax administrator and subsequent refund the same amount of VAT by tax office to buyer (Terra and Kajus, 2015). In theory, the credit-invoice method ensures a self-policing nature of VAT system because each VAT payer should be motivated to get a tax document from his supplier to claim back input VAT (Рomeranz, 2015). However, this system is also administratively demanding as the administrators must check the output tax reported by suppliers and also input tax claims of buyers. Therefore, it would be helpful to express how many inspections by the financial office are needed to collect VAT for public budgets.

The aim of this paper is to evaluate the efficiency of current VAT system based on the number of necessary checks of VAT remitted and refunded in the production and distribution chain. First, we describe the possible approaches how to measure tax collection efficiency, then we introduce our own indicator of efficiency. Subsequently, we calculate the values of this indicator for the Czech Republic for the period 2005 to 2018 and finally we discuss our results.

\section{Literature review}

Since the efficiency is not exactly defined term, different authors might focus on different efficiency interpretation. In literature, three main approaches to calculation of VAT collection efficiency were found.

First approach represents calculation of C-efficiency ratio and VAT gap. Cefficiency ratio constitutes a complex VAT effectiveness coefficient, which shows the difference between tax levied in theoretical standard VAT system ${ }^{3}$ and actual VAT revenue (Keen 2013). C-efficiency ratio is basically influenced by the existence of exemptions, reduced rates and tax evasion. Aizenmann and Jinjarak (2008) explored economic factors affecting C-efficiency ratio and prove its relationship to the stability of political system, urbanization level, trade openness, GDP per capita and the share of agriculture on total production. The latter factor has inverse proportion on C-efficiency value (the higher the share of agriculture in the economy, the lower C-efficiency value), while all the remaining factors have direct proportion (e.g. the higher the urbanization level in the economy, the higher C-efficiency value).

3 System with only one standard rate and all consumption subject to VAT. 
More frequently used indicator of VAT system efficiency is VAT gap. It results from decomposition of C-efficiency ratio into so called "policy gap" and "compliance gap". The policy gap is created by the application of reduced VAT rates and exemptions that cause lower VAT revenues than an ideal VAT system would generate. Compliance gap, in other words the VAT gap, represents the difference between theoretical tax liability of the current system and actual tax revenue. VAT gap consists from tax evasion, but it also contains VAT not collected by the state due to insolvencies. Therefore, VAT gap is used as the approximation of non-compliance level (Poniatowski, 2019). VAT gap is also influenced by many factors. These factors mainly constitute difference between cash and accrual VAT base and tax evasion existence (Keen 2013). The important figure for tax administrators is the share of tax evasion on total VAT gap, because tax evasion represents most undesirable factor. Fearing (2015) describes results acquired by nine EU Member States' Tax Authorities ${ }^{4}$. In average, the value of tax evasion on total VAT gap equate $36 \%$, while $24 \%$ comes under MTIC frauds.

Second approach to VAT collection efficiency searches for administration costs. This approach associates efficiency with minimalization of costs incurred in tax collection. As there are two types of costs, both need to be calculated separately. First type of costs are administrative costs. These costs are spent on the side of tax administrator (public sector) and involves costs of revenue department, costs incurred by other public institutions, judiciary costs and interest costs incurred by loans represented as legal lags in collection (Barbone, Bird, Vázquez Caro, 2012). The other type of administration costs constitutes compliance costs, which are borne by private sector. These costs relate to complying with legal obligations (e.g. tax return filling, reporting, tax depreciation of specialized software).

In the literature, approach via administrative costs is described quite frequently (see e.g. Evans, 2008). However, restriction of this approach represent data, as there is no accurate evidence on VAT costs (or other taxes' costs) themselves. To give some perspective, Barbone, Bird and Vásquez Caro (2012) mention calculation of both types of costs as a ratio of VAT revenue: Administration costs in 2010 in United Kingdom reached value of $0.7 \%$, while compliance costs in 2003 in four European states ${ }^{5}$ equaled values between $0.3 \%$ in Denmark to $2.17 \%$ in Netherlands.

Both previously mentioned approaches are linked in Mello (2008). According to this study, VAT efficiency (measured by C-efficiency ratio) rises with the lower share of administrative costs in tax revenue.

The third approach is the calculation of efficiency through econometrical and statistical methods. Great example of such efficiency measure is a method called Data Envelopment Analysis (DEA). DEA compares inputs and outputs of decision-making units in order to obtain their relative efficiency and is of-

\footnotetext{
4 Austria, Bulgarian, Cyprus, Czech Republic, Finland, France, Slovakia, Slovenia and United Kingdom

5 Denmark, Netherlands, Norway and Sweden
} 
ten used for the evaluation of public sectors, such as health sector (see e.g. Vitezić et al., 2017).

Despite not being frequently used for evaluation of tax administration, there are exceptions. Some authors utilize DEA to reach efficiency of tax administrator (Savić et al., 2015; Alm and Duncan, 2014). Such example is the study of Alm and Duncan (2014), who use DEA analysis to ascertain complex costs' efficiency of tax administrators in 28 OECD countries. Their analysis uses employee costs and IT costs as an inputs and aggregate tax revenue, VAT revenue, CIT revenue and PIT revenue as an outputs. Besides, the same study additionally uses second-stage analysis called Stochastic Frontier Analysis (SFA). SFA is utilized to eliminate influences, which are not under control of decision-making unit (tax administrator in this case). According to Alm and Duncan, such influences are ratio of services and agriculture on GDP and economy openness.

The result of the analysis (Alm and Duncan, 2014) shows that 13 out of 28 countries are relatively efficient at collecting of three types of taxes (CIT, PIT and VAT). Discussing only VAT, 7 of the 27 tax administrators were considered as relatively efficient while collecting this tax.

For the purpose of this paper, different approach was selected. We calculate administration efficiency through a collection coefficient (further referred as "C-Coefficient") using data in a model country (the Czech Republic) for a selected period. C-Coefficient defines the amount of currency units that need to be audited by the tax administrator to reach one currency unit of VAT revenue. The higher the coefficient is, the higher value of transactions needs to be checked by tax authority. Therefore, the higher value indicates less efficient administration system. Such coefficient was not found in the literature ${ }^{6}$.

In standard VAT system, the coefficient must be higher than one. The reason lies in VAT deductions, since the associated remittances need to be controlled two times. Once on the side of suppliers, their output VAT is audited by the tax administrator whether it is reported and remitted in correct amount. For the second time, the recipient's input VAT deduction must be checked for its rightfulness. On the other hand, in the general reverse-charge mechanism, the coefficient might be equal to one due to actual VAT collection on the last link of the supplier chain and no need of auditing any VAT transfers within the distribution chain.

\section{Methods}

\subsection{Calculation of the C-coefficient}

For the purposes of C-coefficient calculation, consumption was divided into two parts: "final" consumption and intermediate consumption. In further text, the "final" consumption refers not only to the final consumption of households but also to transactions between VAT payers and any subjects

6 Only S. Kryl (2018) has mentioned an idea of the coefficient on the Prague's VAT Forum in 2018. 
without VAT deduction right (entrepreneurs - VAT non-payers or a VAT payers who provide VAT exempt supply and, therefore, have no or only partial right to VAT deduction). The intermediate consumption represents transactions between subjects with full VAT deduction right (VAT payers performing fully taxable activity in general).

C-Coefficient is calculated by a top-down approach using macroeconomic data. The C-Coefficient estimates what amount of currency units needs to be audited by tax administrator to collect one currency unit to public budget within current European VAT system. The coefficient is expressed as follows:

$$
\begin{gathered}
\text { Equation } 1 \\
C-\text { Coefficent }=\frac{2 * V R I C+V R}{V R}
\end{gathered}
$$

Where VRIC stands for VAT remitted by suppliers in intermediate consumption and VR means final VAT revenue collected by tax administrator from "final" consumption in the economy, i.e the output VAT staying in public budgets.

Construction of the coefficient is derived from tax administrator's position in the system. The administrator is obliged to check tax payments for goods and services declared by taxpayers (output tax), but also VAT deduction claims (input tax) as required by credit-invoice method of collection. Consequently, there are two payments that need to be inspected in the case of intermediate consumption and one more payment must be audited at the end of the supply chain (or at the moment when the supply is provided to a recipient who does not have full right to deduct input VAT).

Since direct data on the amount of VAT paid from intermediate consumption are not available, these data were determined from total tax paid on local taxable supplies in the economy (in further text referred as "TTO"). TTO can be calculated from the aggregate tax bases contained in the summary statistics from all VAT returns filed with the tax administrator (see equation 3). The VAT paid in intermediate consumption (VR/C) can be calculated as follows.

\section{Equation 2}

$$
V R I C=T T O-V R
$$

TTO does not include VAT paid on cross-border transactions (i.e. intracommunity acquisitions of goods, imports of goods from non-EU countries and purchases of services from abroad). The reason is that cross-border transactions have different regime as described earlier. In such type of transactions, input and output tax are applied together (similarly to reverse-charge mechanism) in one VAT return by the same VAT payer. For the sake of our calculation, we assume that they do not have to be thoroughly inspected as they do not represent real money flows to/from the Financial Authorities. This would however change in the Definitive VAT system if the output tax was applied 
on cross-border supplies by the supplier and the buyer claimed it back. We discuss this issue in the conclusion of the paper.

Accordingly, the calculation of total tax paid on output (TTO) is constructed as follows:

$$
\begin{gathered}
\text { Equation } 3 \\
\text { TTO }=\sum\left(T B_{i} * r_{i}\right)
\end{gathered}
$$

Where TB means tax base and r stands for corresponding tax rate. The ' $i$ ' represents standard or reduced rate used in the economy.

Integrating the equations mentioned above, the C-Coefficient equals:

\section{Equation 4}

$$
C-\text { Coefficient }=\frac{2 * \sum\left(T B_{i} * r_{i}\right)}{V R}-1
$$

Based on equation 4, the C-Coefficient was calculated for the period from 2005 to 2018. This was the longest time series possible to quantify administrative efficiency of VAT collection in time as there was different VAT regime before 2005 (the Czech Republic was not a member of EU).

\subsection{Data sources and restrictions}

We used several sources of data for calculation. Primarily, "Tax statistics" published by Czech Tax Administration Office (Financial Administration, 2020) were utilized. In terms of VAT, tax administration makes publicly available on its website the data from all VAT returns submitted in individual years. These contain the following items?

- aggregate tax bases for local supplies divided for standard and reduced VAT rate

- total claim of VAT on input divided for standard and reduced VAT rate

- total declared tax liability or total excessive VAT claim

Aggregate tax bases from the above statistics were used as TB for the calculation of TTO in equation 3.

Secondary, VAT rates were found in the Czech Act No. 235/2004 (Czech VAT Act) and used as $r_{i}$ in the calculation of TTO in equation 3. The development of Czech VAT rates is shown in next table:

7 All items are further classified into industries according to NACE classification. 
Table 1: The progress of standard and reduced VAT rate in the Czech Republic

\begin{tabular}{|ccc|}
\hline Year & Standard VAT rate & Reduced VAT rate \\
\hline 2005 & $19 \%$ & $5 \%$ \\
2006 & $19 \%$ & $5 \%$ \\
\hline 2007 & $19 \%$ & $5 \%$ \\
\hline 2008 & $19 \%$ & $9 \%$ \\
\hline 2009 & $19 \%$ & $9 \%$ \\
\hline 2010 & $20 \%$ & $10 \%$ \\
\hline 2011 & $20 \%$ & $10 \%$ \\
\hline 2012 & $20 \%$ & $14 \%$ \\
\hline 2013 & $21 \%$ & $15 \%$ \\
\hline 2014 & $21 \%$ & $15 \%$ \\
\hline 2015 & $21 \%$ & $15 \% / 10 \%$ \\
\hline 2016 & $21 \%$ & $15 \% / 10 \%$ \\
\hline 2017 & $21 \%$ & $15 \% / 10 \%$ \\
\hline 2018 & $21 \%$ & $15 \% / 10 \%$ \\
\hline
\end{tabular}

Source: Czech VAT Act, own processing

Since 2015, two reduced VAT rates were applied in the Czech Republic, but the tax base reported in VAT return was not divided accordingly. Consequently, the calculation of TTO based on equation 3 could not be executed accurately with publicly available data. Based on request with the Czech Tax Administration Office, more suitable data on total tax paid from goods and services subject to reduced rates were acquired. Therefore, the TTO for the years 2015-2018 were taken from these additionally obtained data (and not calculated by equation 3).

It should be noted that cash VAT revenues differ from accrual VAT revenues reported in VAT returns for the respective periods. In practice, the VAT payers remit their reported VAT liability to the tax authority bank account within certain period after the VAT return is submitted. Therefore, part of the year's VAT liability is being collected in the future (Keen 2013), which leads to shifting of the VAT collection (and associated tax audits) to following years. For the calculation of the C-Coefficient, the annual data on cash receipts to the financial administration bank account were used. These actual VAT revenues are published by Czech Tax Administration Office (Financial Administration, 2020a) as "Collection statistics". We inserted the data series from 2005 to 2018 from these statistics as $V R$ in equation 2 and equation 1 to calculate the C-Coefficient. 


\section{Results}

Based on the above described methods, C-Coefficient was calculated for the years 2005-2018. The C-Coefficient equates values between 7.23 and 11.56 in selected years in the Czech Republic. The result means that 7.23 (11.56 respectively) CZK need to be inspected by tax administrator to reach one CZK of tax revenue.

The results, including the necessary data obtained or computed for the calculation, are showed in following table.

Table 2: The C-Coefficient and data used for calculation

\begin{tabular}{|ccccc}
\hline Year & $\begin{array}{c}\text { TTO } \\
\text { (CZK mil.) }\end{array}$ & $\begin{array}{c}\text { VR } \\
\text { (CZK mil.) }\end{array}$ & $\begin{array}{c}\text { VRIC } \\
\text { (CZK mil.) }\end{array}$ & C-Coefficient \\
\hline 2005 & $1,182,051$ & 204,941 & 977,110 & 10.54 \\
\hline 2006 & $1,313,412$ & 217,394 & $1,096,018$ & 11.08 \\
\hline 2007 & $1,462,928$ & 235,844 & $1,227,084$ & 11.41 \\
\hline 2008 & $1,600,753$ & 254,939 & $1,345,814$ & 11.56 \\
\hline 2009 & $1,420,331$ & 253,464 & $1,166,867$ & 10.21 \\
\hline 2010 & $1,573,219$ & 269,582 & $1,303,637$ & 10.67 \\
\hline 2011 & $1,597,524$ & 275,188 & $1,322,336$ & 10.61 \\
\hline 2012 & $1,537,185$ & 278,052 & $1,259,133$ & 10.06 \\
\hline 2013 & $1,576,543$ & 308,300 & $1,268,243$ & 9.23 \\
\hline 2014 & $1,655,127$ & 322,662 & $1,332,465$ & 9.26 \\
\hline 2015 & $1,632,473$ & 331,604 & $1,300,869$ & 8.85 \\
\hline 2016 & $1,558,538$ & 349,460 & $1,209,078$ & 7.92 \\
\hline 2017 & $1,586,810$ & 381,435 & $1,205,375$ & 7.32 \\
\hline 2018 & $1,698,770$ & 413,013 & $1,285,757$ & 7.23 \\
\hline
\end{tabular}

Sources: Financial administration (2020) and Financial administration (2020a); own calculation

In 2018, total tax paid for goods and services (TTO) amounted to CZK 1,698,770 million, which equates approximately EUR 63,500 million. From this amount, over $76 \%$ represent VAT paid (and subsequently refunded) in intermediate consumption. That is the reason for rather high C-Coefficient representing the obligation of the tax administrator to audit one CZK collected to public budgets more than 7 times in the year 2018. The year with the highest (worst) C-Coefficient 11.56 was 2008. In that year the financial offices had to inspect each CZK of final VAT revenue more than 11 times. 
It is clear from Table 1 that the C-Coefficient has a decreasing tendency, which shows the improving efficiency in VAT collection. The development of the CCoefficient in the Czech Republic is depicted in the following chart.

Chart 1: The progress of collection coefficient in the Czech Republic

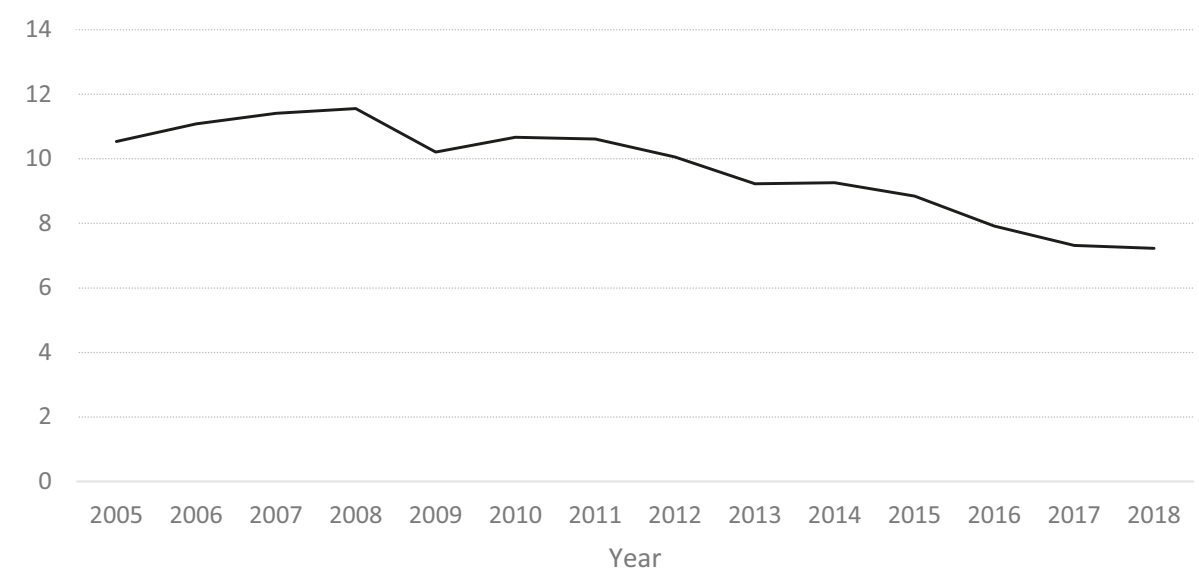

Source: authors

The decreasing tendency indicates that the relative value of audited payments declines, and collection administration efficiency thus improves throughout years 2005 and 2018 in the Czech Republic.

\section{Discussion}

Since 2010, C-Coefficient decreased every year except for the year 2014. In further discussion, we try to explain this decline and find what factors had an impact on it. We also compare our results to findings of other authors in the field of VAT efficiency.

Primarily, the pressure on the increase of VAT revenues and strong tax collection effort might have had impact on C-Coefficient. More effective tax audits and newly implemented anti-fraud technical instruments, e.g. VAT control statement or Electronic record of sales, could have helped to reduce VAT evasion and generate higher final VAT revenue. Increasing final VAT revenue with the level of intermediate consumption staying at the same level reduces the C-Coefficient value. Increasing VAT efficiency during this period reveals also the annually prepared Study on VAT gap for the European Commission (Poniatowski et al., 2019). According to this study, the relative VAT gap in the Czech Republic is gradually decreasing from 19 \% in 2013 to 12 \% in 2017.

Secondly, the average number of taxpayers in the production and distribution chain influences the coefficient's value. The fewer taxpayers are in the supply chain, the fewer transitions are effected in intermediate consumption. In such situation, the tax administrators do not have to check so many VAT 
transfers and the value of the C-coefficient is lower. This can also be derived directly from the way how the C-Coefficient is constructed. VAT collected and subsequently refunded to VAT payers in the course of intermediate consumption does not enter into final VAT revenue (in the denominator of the C-Coefficient) but has to be inspected twice. Therefore, doubled amount of intermediate consumption is part of the C-Coefficient' nominator. It is apparent that higher number of VAT payers and resulting higher volume of intermediate consumption causes the increase of the C-Coefficient.

Thirdly, when considering proportion of the output tax paid on intermediate and "final" consumption, tax rates are also important. Since there is different consumption structure (in a simplified way, companies have different inputs in comparison to individuals), we cannot anticipate the same average VAT rate in both types of consumptions. Assuming certain given proportion of "final" and intermediate consumption that corresponds to the economic reality of the market, the lower is the average tax rate associated with intermediate consumption compared to average tax rate related to final consumption, the lower is collection coefficient. Explanation is following: Proportionally lower tax rate in case of intermediate consumption causes lower VAT paid in output and concurrently lower VAT deduction rights in intermediate consumption, which leads to a reduced volume of VAT to be inspected by the tax administrator throughout the supply chains. However, in practice, it can be expected that the final consumption of households is subject to lower average VAT rates than intermediate consumption. As VAT is considered to be regressive tax in the short term (Slintáková and Klazar, 2006), the reduced VAT rates are often applied on goods and services which are included relatively more in the consumption basket of poorer households. This policy should increase the progressivity of VAT and thus reduce income inequality. Caspersen and Metcalf (1994) discussed this topic in their paper which was focused on potential implementation of VAT in the U.S and elaborated on the nature of VAT and its potential progressivity in a long term/ lifelong perspective. Therefore, it is common tax policy that the items dedicated for final consumption are subject to reduced VAT rates rather than goods and services used in intermediate consumption (e.g. production).

Fourthly, specific reverse-charge applied to selected goods and services has positive impact on the C-Coefficient value. Under the reverse-charge mechanism, tax is levied by purchaser, who has simultaneously VAT deduction right from the same transaction. Thus, the transaction taxed under the reversecharge mechanism is tax neutral and does not involve any money transfers between VAT payers and tax administrators. It is not necessary to inspect the tax neutral transactions. Therefore, the size of the C-Coefficient is decreasing. In recent years, the Czech Republic has extended the list of taxable supplies under the reverse-charge mechanism. In 2011, reverse-charge was applied on emission allowances, certain metals, scrap and waste, followed by reverse charge on construction works in 2012 as well as supply of mobile phones, integrated circuits, game consoles, tablets and other commodities in 2015 (Czech VAT Act). 


\section{Conclusion}

Technical instruments against VAT frauds might have had a positive impact on the administration efficiency of VAT payment collection. They generally improve the VAT collection. One of the measures, the specific reverse charge, causes less payments in the system and, therefore, more effective-oriented control by tax administrator. This is particularly interesting finding for the discussion about the Definitive VAT system currently considered by the European Commission.

As explained earlier, the Definitive VAT system introduces the invoice credit method to cross-border transactions and is practically the opposite of the reverse charge. In the Definitive VAT system not only local transactions but also the sales and purchases between the EU Member States would have to be carefully inspected by the financial authorities. The C-Coefficient would increase because the volume of intracommunity supplies would have to be added to the nominator and doubled. The reason is that not only output tax remitted by the supplier through the One-Stop-Shop in the Member State of origin but also the VAT deduction claimed by the purchaser in the Member State of destination would have to be checked. Moreover, the tax authorities would incur additional administration costs associated with the clearance of VAT on the cross-border sales/purchases with other Member States to/from which the goods are delivered.

Another finding of our analysis is that reducing the average number of taxpayers in the production and distribution chain would improve the efficiency of the VAT collection. However, this would not be desirable in terms of competition. Less subjects in the chain would mean concentrating the suppliers and monopolizing the industries. It is believed that one of the VAT advantages is that it does not disturb the competition on the market (Terra and Kajus, 2015). Therefore, increasing the VAT efficiency by means of limiting the number of VAT payers in the chain would not be the right way forward.

The last point to mention is the importance of the average VAT rates applicable in the economy. Usually, the VAT rate on final consumption is lower than the average VAT rate on intermediate consumption which is the objective of the most tax policy makers. However, this setup further worsens the VAT collection efficiency as the C-Coefficient gets higher. 


\section{References}

Ainsworth, R.T. (2011). VAT Fraud as a Policy Stimulus - Is the US Watching? VAT Withholding, RTvat, and the Mittler Model. Boston University School of Law Working Paper, 11(8). At <http://dx.doi.org/10.2139/ssrn.1769145>, accessed 23 November 2019.

Aizenman, J. and Jinjarak, Y. (2008). The Collection Efficiency of the Value Added Tax: Theory and International Evidence. The Journal of International Trade and Economic Development, 17(3). pp. 391-410. DOI: 10.1080/09638190802137059.

Alm, J. and Duncan, D. (2014). Estimating Tax Agency Efficiency: Estimating Tax Agency Efficiency. Public Budgeting \& Finance, 34(3), pp. 92-110. DOI: 10.1111/pbaf.12043.

Barbone, L., Bird, R.M. and Vázquez Caro, J. (2012). The Costs of VAT: A Review of the Literature. SSRN Electronic Journal, 106. DOI: 10.2139/ssrn.2024880. At <http://www.ssrn.com/abstract=2024880>, accessed 7 March 2020.

Caspersen, R. and Metcalf, G. (1994). Is a value added tax regressive? Annual versus lifetime incidence measures. National Tax Journal, 47(4), pp. 731-746.

Directive 2018/2057, OJ L 329, 20.12.2018, pp. 3-7.

European Commission. (2010). Green paper: On the future of VAT. At <https://ec.europa.eu/taxation_customs/consultations-get-involved/ tax-consultations/green-paper-future-vat-towards-a-simpler-more-robustefficient-vat-system_en>, accessed 23 April 2019.

European Commission. (2018). Proposal for Council Directive amending Directive 2006/112/EC as regards the introduction of the detailed technical measures for the operation of the definitive VAT system for the taxation of trade between Member States. At <https://eur-lex.europa.eu/legal-content/en/ TXT/?uri=CELEX\%3A52018PC0329>, accessed 15 August 2019.

European Court of Auditors. (2016). Tackling intra-Community VAT fraud: More action needed. At <https://www.eca.europa.eu/Lists/ECADocuments/ SR15_24/SR_VAT_FRAUD_EN.pdf>, accessed 5 October 2019.

Evans, C. (2008). Taxation Compliance and Administrative Costs: An Overview. Tax Compliance Costs for Companies in an Enlarged European Community, pp. 447-468.

Fearing et al. (2015). Implementing the "destination principle" to intra-EU B2B supplies of goods: feasibility and economic evaluation study: final report. Luxembourg: Publications Office.

Fedeli, S. and Forte, F. (2011). EU VAT frauds. European Journal of Law and Economics, 31(2), pp. 143-166. DOI: 10.1007/s10657-009-9135-5>, accessed 23 November 2019.

Financial administration. (2020). Tax statistics. At <https://www.financnisprava. cz/cs/dane/analyzy-a-statistiky/danova-statistika>, accessed 26 April 2020.

Financial administration. (2020a). Data on tax collection. At <https://www. financnisprava.cz/cs/dane/analyzy-a-statistiky/udaje-z-vyberu-dani>, accessed 26 April 2020.

Keen, M. (2013). The Anatomy of VAT International Monetary Fund. At: <https:// www.imf.org/external/pubs/ft/wp/2013/wp13111.pdf>, accessed 14 January 2020.

Kryl, S. (2018). Practical Aspects of the new VAT rules [lecture]. VAT Forum. Prague: Chamber of Tax Advisors and the University of Economics in Prague. 
Mello, L. de. (2008). Avoiding the Value Added Tax: Theory and Cross-Country Evidence. Public Finance Review. DOI: 10.1177/1091142108316588.

Pomeranz, D. (2015). No Taxation without Information: Deterrence and SelfEnforcement in the Value Added Tax. American Economic Review, 105(8). pp. 2539-69. DOI: 10.1257/аer.20130393.

Poniatowski, G. et al. (2019). Study and Reports on the VAT Gap in the EU-28 Member States: 2019 Final Report. Warsaw: CASE. At <https://ec.europa. eu/taxation_customs/sites/taxation/files/vat-gap-full-report-2019_en.pdf>, accessed 8 November 2019.

Savić, G. et al. (2015). Impact of the efficiency of the tax administration on tax evasion. Economic research-Ekonomska istraživanja, 28(1), pp. 1138-1148.

Slintáková, B. and Klazar, S. (2010). Impact of harmonisation on distribution of VAT in the Czech republic. Prague Economic Papers. DOI: 10.18267/j.pep.368

Vitezić, N., Šegota, A. and Setnikar Cankar, S. (2017). Measuring the Efficiency of Public Health Services by DEA. Central European Public Administration Review, 14(4), pp. 27-48. DOI: 10.17573/ipar.2016.4.02

Terra, B. and Kajus, J. (2015). A guide to the European VAT Directives. Hoorn: IBFD. 